\title{
Pengaruh Pemberian Buah Pisang Mas Terhadap Peningkatan Kadar Hb Pada Ibu Hamil Trimester III
}

\author{
Elsa Kumala Safitri ${ }^{1}$, Miftahul Mualimah ${ }^{2}$, Herliana Riska ${ }^{3}$ \\ ${ }^{1,2}$ Prodi DIV Bidan Universitas Kadiri, Jalan Selomangleng No. 1, Kec. Mojoroto - Kota Kediri - Prov. Jawa \\ TimurKediri, Jawa Timur 64115, Indonesia \\ ${ }^{3}$ Prodi S1 Profesi Bidan, Universitas Respati Yogyakarta, Jalan Raya Tajem KM.1,5, Maguwoharjo, Depok, Kenayan, \\ Wedomartani, Kec. Ngemplak, Kabupaten Sleman, Daerah Istimewa Yogyakarta 55282, Indonesia
}

\begin{tabular}{l}
\hline ARTICLE INFORMATION \\
\hline Article Trace \\
Submission: July, 10, 2019 \\
Final Revision: September 01, 2019 \\
Available online: October 29, 2019 \\
\hline
\end{tabular}

\section{Kata kunci :}

Kata kunci : Hemoglobin, Ibu hamil, Pisang mas

\section{Key Word :}

Hemoglobin, pregnant women, Banana mas

\section{Contact:}

herlianariska@respati.ac.id

\begin{abstract}
A B S T R A K
Hemoglobin adalah protein yang kaya akan zat bezi, Memiliki afinitas (daya gabung) terhadap oksigen dan dengan oksigen itu membentuk oxihemoglobin di dalam sel darah merah. Tujuan dalam penelitian ini yaitu untuk mengetahui pengaruh buah pisang mas terhadap peningkatan hemoglobin pada ibu hamil trimester III di BPM Ny"B" Ngasem Kab.Kediri Tahun 2017. Penelitian ini menggunakan metode Eksperiment dan pendekatan Pre Eksperiment dengan Purposive Sampling. Penelitian ini dilakukan di BPM Ny"B" Ngasem Kab.Kediri Tahun 2017. Instrumen yang di gunakan adalah lembar observasi, analisa data dengan iji Wlcoxon Signed Rank.Hasil penelitian buah pisang mas pada ibu hamil trimester III ini bahwa besarnya nilai $\rho 0,000$ lebih kecil dari nilai $\alpha=0,05(0,000<0,05)$ sehingga $\mathrm{H} 0$ ditolak dan $\mathrm{H} 1$ diterima berarti ada pengaruh kadar hemoglobin sebelum dan sesudah diberikan pisang mas terhadap peningktan kadar hemoglobin pada ibu hamil Trimester III di BPM Ny.”B' Ngasem Kab.Kediri tahun 2017. Dengan hal ini di harapkan mengkonsumsi buah pisang mas pada ibu hamil trimester III dapat membantu menurunkan anemia dengan praktis
\end{abstract}

\begin{abstract}
A B S T R A C T
Hemoglobin is a protein-rich substance bezi, Have affinity (power team) against oxygen and with oxygen it forms a oxihemoglobin in red blood cells. The goal in this research is to know the influence of banana fruit mas to increased hemoglobin on pregnant women trimester III in BPM Ny "B" Ngasem Regency Kediri Year 2017. In this research method using alphabets experiment and approach Pre alphabets experiment with Purposive Sampling. This research was conducted in BPM Ny "B" Ngasem Regency Kediri Year 2017. Instruments in use are sheets of observation, data analysis with the iji Wlcoxon Signed Rank. Results of research of banana fruit mas on pregnant women this trimester III that the magnitude of the value of $\rho$ is less than the value of $0.000 \alpha=0.05$ $(0.000<0.05)$ so that $\mathrm{H} 0$ is rejected and the $\mathrm{H} 1$ is accepted means there is influence of hemoglobin levels before and after the given bananas mas against peningktan the levels of haemoglobin in pregnant women Trimester III in BPM Ny. " B “ Ngasem Regency Kediri year 2017. With this expected to consume fruit banana mas on pregnant women may help lower III trimester anemia with practical.
\end{abstract}




\section{PENDAHULUAN}

Anemia dalam kehamilan adalah konsentrasi hemoglobin $(\mathrm{Hb})$ kurang dari $11 \mathrm{~g} / \mathrm{dl}$. Menurut WHO, anemia dianggap memiliki signifikansi atau masalah kesehatan masyarakat jika studi populasi menemukan prevalensi anemia sebesar $5,0 \%$ atau lebih tinggi. Prevalensi anemia $\geq 40 \%$ dalam suatu populasi diklasifikasikan sebagai masalah kesehatan masyarakat yang parah.

Data global menunjukkan bahwa $56 \%$ wanita hamil di negara berpenghasilan rendah dan menengah (LMIC) menderita anemia (Black 2013). Menurut data dari dinas kesehatan kota Kediri melaporkan bahwa pada tahun 2014 jumlah ibu hamil yang mengalami anemia adalah 250 orang dari 5.225 orang $(4,78 \%)$, sedangkan pada tahun 2015 adalah 217 orang dari 4634orang $(4,68 \%)$ dengan demikian, presentase ibu hamil yang mengalami penurunan sebesar 0,1\% (Dinas Kesehatan Kota Kediri, 2016). Anemia pada kehamilan meningkatkan risiko morbiditas dan mortalitas ibu dan perinatal, dan dikaitkan dengan persalinan prematur dan berat lahir rendah.Anemia dalam kehamilan menyebabkan abortus, kehamilan premature, molahidatidosa, hiperemesis gravidarum, perdarahan antepartum, dan KPD (Ketuban Pecah Dini), sedangkan pada saat persalinan akan menyebabkan gangguan his, kala I \& II lama, kala III uri dapat diikuti retensio plasenta dan perdarahan post partum karena atonia uteri, kala IV dapat terjadi perdarahan post partum sekunder dan selanjutnya pada masa nifas akan menyebabkan subinvolusi uteri yang akan menimbulkan perdarahan post partum, pengeluaran ASI berkurang, terjadi dekompensasi kordis mendadak setelah persalinan, anemia kala nifas dll (Ononge, 2014)

Anemia dalam kehamilan yang disebabkan karena kekurangan zat besi, dapat dilakukan pengobatan relatif secara mudah dan murah. Salah satu alternatifnya adalah mengonsumsi dua buah pisang setiap harinya untuk memenuhi asupan zat besi bagi pasien anemia.Terlebih buah pisang mengandung asam folat yang mudah diserap janin melalui rahim. Asam folat (vitamin B6) 0,4 mg merupakan jenis vitamin yang larut dalam air dan secara alami terkandung dalam makanan. Penelitian juga menunjukkan bahwa buah pisang mas dapat meningkatkan eritrosit, hemoglobin, dan hematokrit pada mencit yang anemia (Cholil, 2017).

Pisang Mas memiliki nama ilmiah Musa acuminata Colla (AA Group) atau disebut juga dengan 'Lady's Finger'. Musa acuminata adalah tanaman dari daerah tropis dan subtropis. Selama beberapa dekade terakhir, manfaat kesehatan dari M. acuminata telah menerima banyak perhatian. Semua bagian tanaman termasuk buah-buahan, kulit, pseudostem, umbi, bunga, daun, getah dan akar telah ditemukan digunakan dalam pengobatan banyak penyakit dalam pengobatan tradisional (Ortiz,2017)

Tujuan Penelitian ini adalah untuk mengetahui pengaruh konsumsi buah pisang mas Musa acuminata Colla atau terhadap perubahan tingkat anemia pada ibu hamil di BPM Ny"B"

\section{METODE PENELITIAN}

Berdasarkan tujuan penelitian, penelitian ini merupakan penelitian pre eksperimental. Berdasarkan sumber data merupakan penelitian primer. Desain penelitian one group pre post test design. Penelitian ini dilakukan di BPM Ny"B" di wilayah Ngasem Kab Kediri Tahun 2017.

Populasi penelitian ini adalah semua ibu hamil trimester III yang mengalami Anemia Di BPM Ny"B” di Ngasem Kab Kediri Tahun 2017. Sampel penelitian ini adalah sebagian ibu hamil trimester III dengan Anemia Di BPM Ny"B" di Ngasem Kab Kediri Tahun 2017 yang memenuhi kriteria inklusi dan eksklusi.

Jenis instrument yang digunakan dalam penelitian ini adalah kuisioner sebelum dan sesudah di berikan pisang mas. Dosis pisang mas yang direkomendasikan adalah $3 \times 3$ biji (120gram) setiap harinya selama 1 minggu. Lembar observasi di gunakan untuk mengumpulkan data dengan mengamati dan mengetahui kepatuhan mengikuti terapi dan perubahan Anemia pada ibu hamil trimester III.

Uji statistic menggunakan uji $\mathrm{t}$ sampel berpasangan (Paired $t$ Test) untuk membandingkan nilai rerata kelompok sebelum dan sesudah perlakuan, dengan tingkat kemaknaan yang digunakan adalah $\mathrm{a}=0,05$. Pada populasi dilakukan uji normalitas shapiro wilk. Apabila memenuhi syarat parametrik 
dengan distribusi data normal maka digunakan uji t berpasangan. Jika setelah dilakukan uji normalitas data tidak memenuhi syarat uji parametrik maka menggunakan Uji Wilcoxon Signed Rank Test. Untuk membaca hasil statistiknya dengan melihat nilai statistic uji > nilai tabel atau nilai tingkat kemaknaan yang diperoleh (p) Value $<$ a, nilai $\mathrm{a}=0,05$ dan nilai IK (Interval Kepercayaan)

\section{HASIL DAN PEMBAHASAN}

\section{Tabel 1 Karakteristik Responden berdasarkan usia responden}

\begin{tabular}{lcc}
\hline Usia & $\mathbf{n}$ & $\mathbf{\%}$ \\
\hline$<25$ Tahun & 4 & 19,0 \\
26-30 Tahun & 12 & 57,1 \\
31-35 Tahun & 5 & 23,8 \\
$>$ 36 Tahun & 0 & 0 \\
\hline Total & 21 & 100,0 \\
\hline
\end{tabular}

Berdasarkan data yang diperoleh pada tabel 1 dapat diinterpretasikan bahwa sebagian besar responden $(57,1 \%)$ responden berumur 26-30 tahun. Usia berkaitan erat dengan kadar $\mathrm{Hb}$ hemoglobin didalam tubuh. Ibu yang beresiko $(<20$ dan $>35$ tahun $)$ mempunyai kecenderungan 3 kali untuk terkena anemia dibandingkan dengan umur ibu yang tidak beresiko. Semakin bertambah usia manusia maka akan semakin mengalami penurunan fungsi sel darah merah. Selain itu sistem pencernaan dalam penyerapan zat yang dibutuhkan oleh tubuh terutama dalam penyerapan $\mathrm{Fe}$ didalam tubuh berkurang (Fitarina, 2014).

\section{Tabel 2 Peningkatan Hb Sebelum dan sesudah di Beri Pisang Mas}

\begin{tabular}{lcccccc}
\hline & n & min & max & Mean & $\begin{array}{l}\text { Std. } \\
\text { Deviation }\end{array}$ & Value \\
\hline Hb_Sebelum & 21 & 8 & 10 & 9,10 &, 819 & \\
\hline Hb_Ssetelah & 21 & 9 & 12 & 10,05 &, 921 & 0.000 \\
\hline
\end{tabular}

Berdasarkan data yang diperoleh pada tabel 2 dapat diinterpretasikan bahwa rata-rata kadar $\mathrm{Hb}$ ibu hamil trimester III sebelum diberikan pisang mas yaitu 9,10 g/dl. Rata-rata $\mathrm{Hb}$ ibu hamil trimester III sesudah diberikan pisang mas yaitu $10,05 \mathrm{~g} / \mathrm{dl}$.

Setelah di mengkonsumsi buah pisang mas, hemoglobin menjadi naik dari rerata 9,10 g/dl. Menjadi 10,05g/dl.

Berdasarkan hasil analisa uji normalitas pada tabel 2, diperoleh nilai signifikasi untuk anemia sebelum di berikan treatment sebesar 0,002, sedangkan nilai signifikasi untuk anemia sesudah di berikan treatment sebesar 0,00. Karena nilai signifikasi peningkatan hemoglobin sebelum dan sesudah kurang dari 0,05, maka dapat di simpulkan bahwa data peningkatan hemoglobin baik sebelum maupun sesudah di berikan treatment berdistribusi tidak normal sehingga perlu dilakukan uji selanjutnya yaitu uji wilcoxon. Berdasarkan Hasil analisa uji statistic dengan menggunakan uji wilcoxon Signed Rank dengan SPSS versi 16,00, pada tabel rank di dapatkan negative rank 0 , positive rank 19 yang berarti ada 19 responden yang mengalami kenaikan hemoghlobin setelah di berikan treatment dan Ties 2 yang berarti ada 2 responden yang tidak ada perubahan terhadap anemia setelah diberikan treatment.

Sedangkan pada tabel test statistic menunjukan bahwa $P$ Value di dapatkan Asymp.Sig. (2tailed) 0,000 dimana nilai $\mathrm{P}<$ sehingga $P$ Value $<\alpha$ maka $\mathrm{H}_{0}$ ditolak dan $\mathrm{H}_{1}$ diterima hal ini menunjukkan ada Pengaruh pemberian pisang mas Terhadap peningkatan kadar Hemoglobin pada ibu hamil trimester III.

Berdasarkan hasil penelitian didapatkan bahwa rata-rata kadar Hemoglobin ibu hamil trimester III sesudah diberikan buah pisang mas yaitu $10,05 \mathrm{~g} / \mathrm{dl}$.Peningkatan kadar hemoglobin tersebut terjadi karena adanya kandungan zat besi. Pemberian buah pisang mas selama 1 minggu dilakukan dengan baik dan reponden mematuhi anjuran yang diberikan peneliti. Pemberian pisang mas sebanyak 3x 3biji per responden dilakukan pada pagi hari siang hari dan malam hari dan penelitian ini sesuai dengan SOP.

Berdasarkan hasil penelitian yang disajikan dalam tabulasi silang menunjukkan bahwa dari total 20 responden $(100 \%)$ yaitu pada sebelum perlakuan rata-rata kadar Hemoglobin ibu hamil trimetster III yaitu $9,10 \mathrm{~g} / \mathrm{dl}$ dan setelah diberikan diberikan pisang mas responden 
mengalami peningkatan kadar hemoglobin yaitu dengan rata-rata $10,05 \mathrm{~g} / \mathrm{dl}$.

Hasil analisa dari uji statistic dengan wilcoxon signed rank antara sebelum dan sesudah pemberian pisang mas terhadap peningkatan kadar Hemoglobin pada ibu hamil trimester III bahwa besarnya nilai $\rho$ 0,000 lebih kecil dari nilai $\alpha=0,05(0,000<0,05)$ sehingga $\mathrm{H} 0$ ditolak dan H1 diterima berarti ada pengaruh kadar hemoglobin sebelum dan sesudah diberikan pisang mas terhadap peningktan kadar hemoglobin pada ibu hamil Trimester III di BPM Ny."B' Ngasem Kab.Kediri tahun 2017. Keeratan hubungan diatas dianalisa menggunakan komputerisasi dengan bantuan aplikasi SPSS dengan tingkat signifikan 0,05 sehingga dpat disimpulkan bahwa sebelum dan setelah perlakuan terdapat peningkatan kadar hemoglobin.

Pisang memiliki nilai gizi yang sangat baik yang merupakan kombinasi dari nilai energi, elemen pembangun jaringan, protein, vitamin dan mineral. Kandungan tersebut merupakan sumber kalori yang baik karena kaya akan padatan dan kadar air yang rendah dibandingkan dengan buah segar lainnya. Pisang adalah sumber Vitamin C yang baik yang membantu membangun kembali sistem kekebalan tubuh. Vitamin $\mathrm{C}$ dalam pisang juga meningkatkan penyerapan zat besi dan meningkatkan pembentukan darah yang sangat cocok untuk mengatasi anemia atau masalah terkait darah (Kumar, 2012).

Pada penelitian ini terdapat responden yang tidak mengalami peningkatan kadar Hemoglobin. Hal ini menunjukkan bahwa kadar hemoglobin dapat dipengaruhi oleh beberapa faktor lain diantaranya adalah kebiasaan hidup, makanan, sosial ekonomi, pola makan, pengetahuan, pendidikan dan budaya. Di negara-negara berkembang, penyebab anemia selama kehamilan adalah multifaktorial, termasuk kekurangan gizi zat besi, folat, dan vitamin B12 dan juga penyakit parasit, seperti malaria dan infeksi parasit usus. Kontribusi relatif dari masing-masing faktor ini terhadap anemia selama kehamilan sangat bervariasi berdasarkan lokasi geografis, musim, dan praktik diet (Asrie, 2017).

Strategi untuk mencegah dan mengendalikan kekurangan zat besi termasuk mengurangi kemiskinan, meningkatkan sistem kesehatan dan ketahanan pangan, mengurangi kehilangan zat besi, meningkatkan bioavailabilitas besi dalam makanan, dan meningkatkan asupan zat besi. (Allen, 2006)

Menggunakan pisang sebagai makanan alternatif untuk meningkatkan zat besi dapat menjadi strategi yang efektif untuk meningkatkan asupan zat besi dalam populasi dengan asupan pisang yang tinggi dan prevalensi defisiensi besi dan anemia yang tinggi. Penyerapan zat besi dari pisang mentah sangat tinggi. Hal ini disebabkan karena peningkatan signifikan karbohidrat larut yang meningkatkan kelarutan besi. Sekitar 50\% zat besi yang dikonsumsi dalam pisang mentah diserap. (Garcia, 2015).

Penelitian sebelumnya di Amerika Serikat yang menyatakan bahwa buah pisang mengandung zat besi yang akan menstimulus produksi hemoglobin dalam darah dan juga membantu mencegah anemia. Vitamin c yang terkandung dalam pisang juga bagus untukkesehatan untuk membantu membangun kembali sistem kekebalan tubuh. Pisang juga makanan yang relatif mudah dicerna dibandingkan makanan yang lain sehingga mempermudah seseorang dengan sistem kekebalan tubuh yang rendah. Vitamin $\mathrm{C}$ juga meningkatan penyerapan besi dan meningkatkan pembentukan darah, dua manfaat kesehatan ini membuat pisang berguna untuk tambahan dalam menu makanan mereka dalam menanggulangi anemia (Anhawange, 2008)

\section{KESIMPULAN}

1. Sebelum pemberian buah pisang mas sebagian besar responden mengalami anemia tingkat berat sedang ringan.

2. Setelah pemberian buah pisang mas sebagian besar responden mengalami peningkatan $\mathrm{HB}$ cenderung kearah rentang normal

3. Terdapat pengaruh signifikan secara statistic yang menunjukkan bahawa buah pisang mas dapat meningkatkan kadar HB ibu hamil trimester III 


\section{DAFTAR PUSTAKA}

Allen LH, de Benoist B, Dary O, Hurrel R, 2006. World Health Organization and Food and Agriculture Organization of the United Nations. Guidelines on food fortification with micronutrients.

Anhwange, B. A., 2008, Chemical Composition of Musa sapientum (Banana) Peels,Journal of Food Technology

Asrie F., 2017. Prevalence of anemia and its associated factors among pregnant women receiving antenatal care at Aymiba Health Center, northwest Ethiopia. Journal of Blood Medicine » Volume 8

Black R. E., Victora C. G., Walker S. P., et al. Maternal and child undernutrition and overweight in low-income and middleincome countries. 2013;382(9890):427451. doi: 10.1016/S0140-6736(13)60937$\mathrm{X}$

Cholil, 2017. Pengaruh Pemberian Buah Pisang Mas (Musa acuminata C.) Terhadap Eritrosit, Hemoglobin, Dan Hematokrit Pada Mencit yang Anemia. Skripsi. Politeknik Kesehatan Kemenkes Surabaya.

Dinas Kesehatan Provinsi Jawa Timur. 2010. Profil Kesehatan Provinsi Jawa Timur Tahun 2010 : Dinas Kesehatan Jawa Timur

Dinas Kesehatan Provinsi Jawa Timur. 2012. Profil Kesehatan Provinsi Jawa Timur Tahun 2012 : Dinas Kesehatan Jawa Timur
Dinas Kesehatan Provinsi Jawa Timur. 2014. Profil Kesehatan Provinsi Jawa Timur Tahun 2012 : Dinas Kesehatan Jawa Timur

Fitarina, 2014. Faktor-Faktor Yang Berhubungan Dengan Kejadian Anemia Pada Ibu Hamil. Jurnal Kesehatan Metro Sai Wawai Volume VII No.1 Edisi Juni 2014, ISSN: 19779-469X

Garcia, O, et al. 2015. Iron Absorption In Raw and Cooked Bananas: a field study using stable isotopes in women. Journal food and Nutrition Reasearch. 59: 10.3402/fnr.v59.25976.doi: 10.3402/fnr.v 59.25976

Ononge S., Campbell O., Mirembe F. Haemoglobin status and predictors of anaemia among pregnant women in Mpigi, Uganda. 2014;7(1, article no. 712) doi: $10.1186 / 1756-0500-7-712$

Ortiz L, et al, 2017. Use of Banana (Musa acuminata Colla AAA) Peel Extract as an Antioxidant Source in Orange Juices. Plant Foods Hum Nutr. Mar;72(1):60-66. doi: 10.1007/s11130-016-0591-0.

Kumar, S.K.P. et al, 2012. Traditional and Medicinal Uses of Banana. Journal of Pharmacognosy and Phytochemistry. ISSN 2278- 4136 ZDB-Number: 2668735-5 IC Journal No: 8192 Volume 1 Issue 3

World Health Organization. 2001.

World Health Organization. 2008. 